\title{
Using different mapping techniques and GIS programs in the analysis and visualisation of mental maps
}

\begin{abstract}
The paper presents the review of mapping techniques applied in research using mental maps. The review covers both evaluative and structural mapping. The choice of a method is influenced by the level of freedom given to the respondents while creating sketch maps. It is also highly affected by the area of a given region, scale used in the research and limitations of mapping techniques in GIS software. For large scale maps created in GIS software, it is possible to use quantitative methods, i.e. proportional symbol maps or quantitative signature symbols. Using multiple complementary mapping techniques allows to draw the most comprehensive conclusions in the analyses of perception of a given space in the society.
\end{abstract}

Keywords: mental maps, mapping techniques

\section{Introduction}

The perception of the surrounding space is different for everyone. Individual cognitive skills, experiences, personal traits, and life priorities affect our view of reality. Kevin Lynch (1960) in his book "The Image of the City" introduced the method of analysing the way people perceive the space by using the city sketches created by its citizens. His research showed differences in perceiving the city by groups and by individuals. Numerous researchers followed the methodology presented by Lynch, and mental maps are frequently used in various studies (Comenetz, 2005; Kum \& Ujang, 2012; Latypova et al., 2021; Nieścioruk, 2016). At first, it is necessary to explain the term mental map used in the present paper. As Błahut (2013) states, it will be assumed that mental maps are the outcomes of conceptualisation of space, places, objects, and their interrelationships through specific categories in memory and imagination, obtained through sensorimotor and emotional experiences. A similar explanation of mental maps is provided by Nieścioruk (2019a).
The author also distinguishes sketch maps which are physical representations of mental maps developed, stored and evolving in people's minds. This is how the term sketch map will be used in the present paper. The aggregation of city images, more precisely: their mental maps, collected from different individuals is possible thanks to conducting surveys involving the creation of sketch maps. Hence, there is a following dependency: mental map $\rightarrow$ sketch map. In order to simplify terminology within this paper, the term mental map will be mostly used, also when referring to sketch maps. The trend started by Lynch is called structural mapping. It is focused on analysing the structures of representation of space stored in people's minds. Another pioneer of research using mental maps was Gould (1966). The trend which originates from his studies is called evaluative mapping and is based on methods of evaluating (assigning values) the surrounding space.

Mental maps are used in research conducted in numerous domains. These are, among others: education and evaluation of education (Castellar 
\& Juliasz, 2018; Nieścioruk, 2016, 2019b; Rédei et al., 2011; Żyszkowska, 1996), urban studies (Jarecka-Bidzińska, 2021; Jász, 2018; Sulsters, 2005), spatial management (Sobala-Gwosdz, 2018), studies on urban space perception (Brennan-Horley \& Gibson, 2009; Nieścioruk, $2019 \mathrm{~b}$ ), and other geography-related issues (Bláha \& Nováček, 2016). Mental maps also attract attention of cartographers (Gendźwiłł, 2009), geographers (Kitchin, 1994) and psychologists (Birnbaum et al., 1989). Bearing in mind a growing number of maps created by amateur cartographers, which are related to mental maps, there is a need for research in this field. The present paper aims at answering this need.

\section{Types of background maps in mental maps studies}

The literature provides a wide range of research using different background maps for mental mapping - from completely blank pages to simplified topographic maps of a given area. Background maps presenting a lot of content are used particularly in evaluative mapping. Such an approach was used, for example, in the research conducted in Darwin city, Australia (Brennan-Horley \& Gibson, 2009). The authors conducted a survey in which the respondents were asked to mark their answers on a pre-prepared map with a basic street layout, names and boundaries of districts, specific areas, i.e.
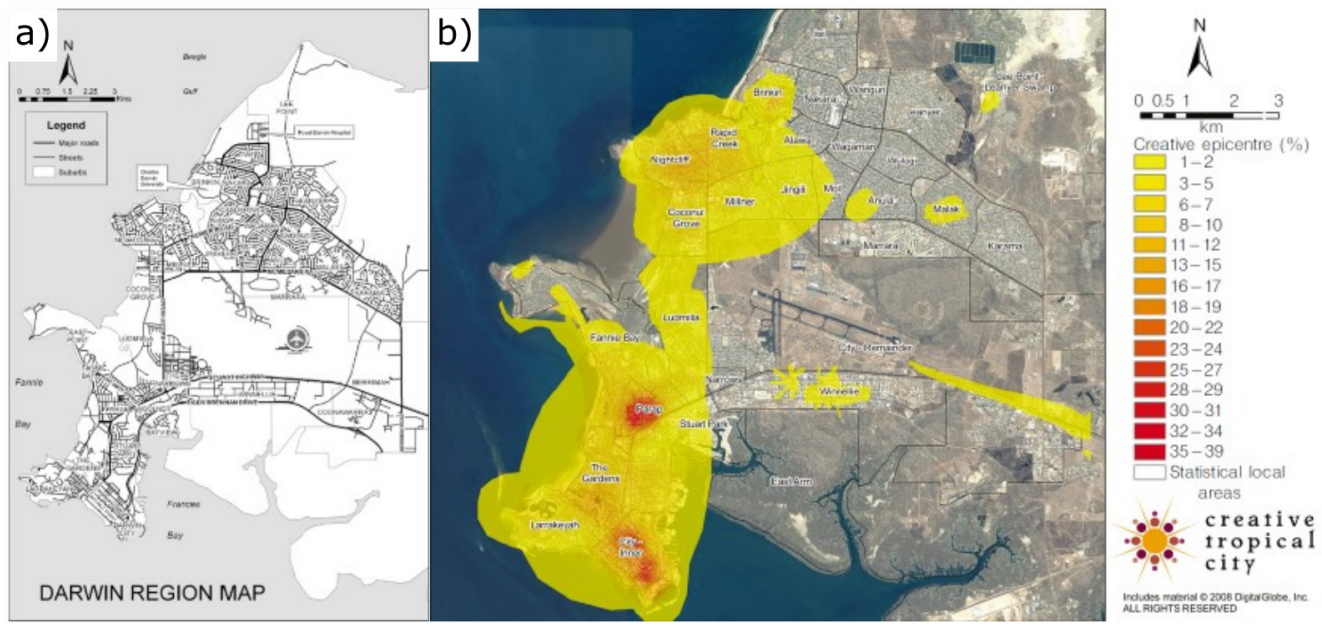

Fig. 1. Evaluative mapping of the city of Darwin, Australia: a) background map for creating sketch maps, b) map of the epicentres of creativity based on the answers (Brennan-Horley \& Gibson, 2009)

Gendźwiłł (2009) in his work provided a detailed description of two trends present in the studies on mental maps, along with applied mapping techniques. His work is particularly valuable because it structures the available information well. However, his paper does not exhaust the topic of possible mapping techniques used for presentation of mental maps. The present article describes further methods of visualisation, which were not addressed by Gendźwiłł. Section 3 describes a methodology proposed by the present author for studying and creating mental maps in GIS software. airport, city hospital, university, coastline and city boundaries (fig. 1a). On the one hand, such an approach facilitates future analyses of the answers in GIS software but, on the other hand, some answers might be suggested to the respondents. Figure $1 \mathrm{~b}$ presents a map using isopleths with a pseudo-continuous scale (it is not possible to differentiate hues between neighbouring classes). The researchers also created a standard choropleth map picturing creativity in the districts of Darwin city.

Another method in terms of background maps used in the research of mental maps is 


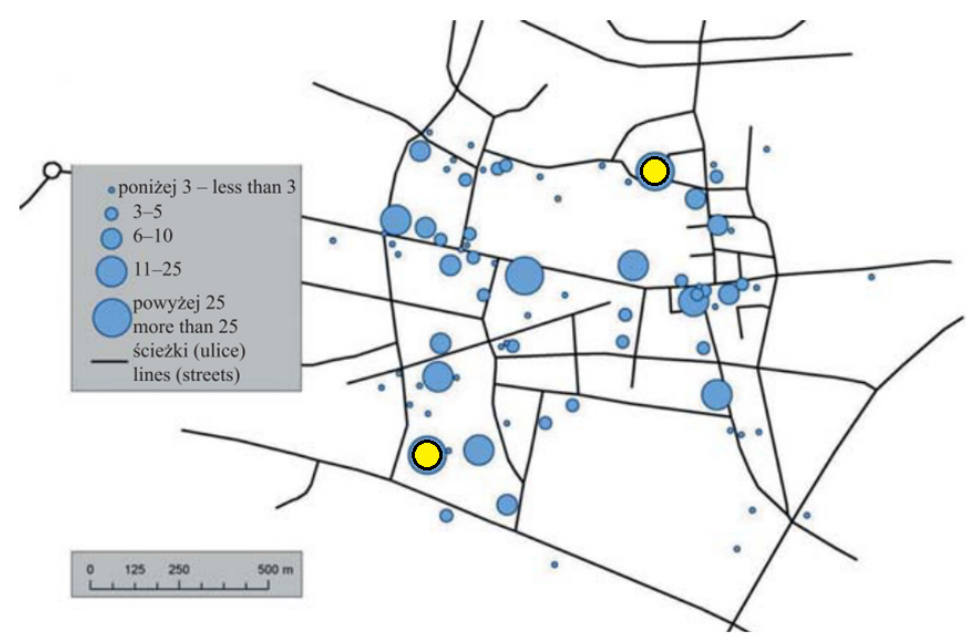

Fig. 2. An example of using benchmarks in surveys - one of the results concerning the number of indications of particular landmarks (the original figure was changed by adding yellow circles - benchmarks) (Nieścioruk, 2013)

to ask the respondents to recreate a certain area on a completely blank page, without any boundaries. In such research, the respondents can fully express their notion of space, which results in great difficulties with cartographic aggregation of the content of mental maps. Such an approach was used in research among citizens of Zielona Góra, Poland (Bazan-Krzywoszańska et al., 2015), or visitors of the World Heritage Sites of Macau (Lee et al., 2018). The authors of the aforementioned studies present their results as textual descriptions and tabular summaries. Based on these outcomes, it is possible to create a classical collective map with quantitative signature symbols using the Lynch's method (Tobiasz-Lis, 2008).

Between these two extreme approaches, one can notice using benchmarks, reference objects in surveys. In such a case, during conducting the survey, the respondents are given a background map with already marked one or more objects which can be easily identified. A mental map which is captured on paper is created with reference to these objects. Such a method makes it possible to compare the respondents' answers but, at the same time, it imposes the direction or orientation of a sketch map. This approach was implemented by Nieścioruk (2013) in the analysis of urban space perception of the city of Lublin, Poland. The respondents were asked to sketch a certain part of the city, located between two specified buildings. It allowed to compare the answers and create summary maps.

\section{GIS software in analysing mental maps}

The author of the present article, based on numerous studies, proposed his own approach towards conducting surveys in research using mental maps. The respondents are given full freedom of expression on a paper sheet with priorly marked benchmarks (fig. 3). Priorly marked benchmarks allow to limit the space which will be described by the respondents, and additionally, they make it possible to digitize and georeference the sketches. Such an approach is partly related to the method proposed by Żyszkowska who used it for mapping differences in marking locations (Żyszkowska, 1996). In her research, the respondents were asked to draw the boundaries of Poland and mark the cities which they were familiar with. Although during the survey the respondents were not limited by anything, while analysing the results Żyszkowska decided to use two cities - Kraków and Gdańsk - as benchmarks. Hence, the approach proposed by the author of the present article is not novel but it develops concepts described in the literature, and adapts them to research in large scales and with using GIS software. 
a)

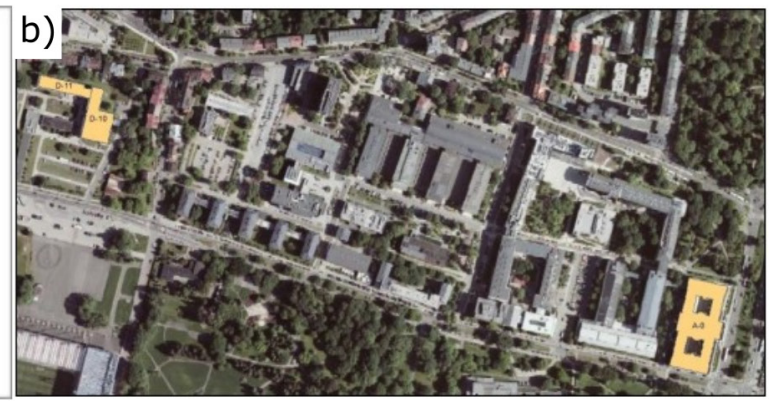

Fig. 3. An example of benchmarks - buildings - used for analysing the perception of a part of AGH UST Campus with mental maps: a) paper sheet with marked reference objects, b) benchmarks presented with an orthophotomap in the background (Ujma, 2017)

The benchmarks are not always buildings. In the case of examining a part of AGH UST Student Campus (fig. 3) the choice of buildings used as benchmarks was obvious. One of these buildings was the Rector's Office (A-0) and another one - Centre of Foreign Languages (D-11). ${ }^{1}$ In the research conducted in the city centre of Tarnów, the benchmarks were major crossroads. ${ }^{2}$ In the research of the perception of the city centre in Gorlice, the benchmarks were a street with surrounding square and a roundabout. ${ }^{3}$

After collecting the answers involving sketch maps, visual representations of mental maps are scanned and georeferenced. This can be done in a selected GIS software, e.g. ArcGIS ArcMap, ArcGIS Pro, QGIS, etc. All the objects marked on a sketch map by particular respondents are then identified. Source data for the identification of objects were either OpenStreetMap data (open database) or BDOT10k data

\footnotetext{
${ }^{1}$ Research conducted as the part of the master thesis by Patrycja Ujma, MEng: "Mental maps in the analyses of the perception of AGH UST Campus in the ArcGIS software" 2017 (Department of Integrated Geodesy and Cartography, AGH UST, thesis supervisor Stanisław Szombara, PhD).

${ }^{2}$ Research conducted as the part of the master thesis by Kinga Kara-Ruta, MEng: "Mental maps in the analyses of the perception of the surroundings of Tarnów city centre in the ArcGIS software" 2019 (Department of Integrated Geodesy and Cartography, AGH UST, thesis supervisor - Stanisław Szombara, PhD).

${ }^{3}$ Research conducted as the part of the master thesis by Iga Joanna Gorczyca, MEng: "Mental maps in the analyses of the perception of Gorlice city centre" 2020 (Department of Integrated Geodesy and Cartography, AGH UST, thesis supervisor - Stanisław Szombara, PhD).
}

(national database). The identified objects are then assigned values which are stored in a spatial database. The objects which can be identified with no doubts are given the value of 1 . The ones whose interpretation raises doubts are assigned the value of 0.5 . These can be paths (roads, streets) which were not labelled by the respondents, even though they were told so by the person conducting the survey. These can also be buildings whose location with reference to neighbouring buildings is doubtful. Alternatively, all the objects present on a mental map can be assigned the value of 1 , irrespectively of the quality of their representation. Such an approach allows to perform queries and to cartographically visualise the answers of different groups of respondents on summary maps. It is also possible to easily adapt mapping techniques to data. The proposed methodology is presented in figure 4. Dashed lines in the diagram indicate secondary influence. For example, the selection of AGH UST Campus as a research area imposed the focus on conducting a social survey with questions enabling the differentiation of students by different criteria (e.g. year of study, place of accommodation: AGH UST Campus, Kraków, other, etc.).

\section{Mapping techniques in structural and evaluative mapping}

\subsection{Qualitative methods}

One of the most frequently implemented mapping techniques used in visualising the 


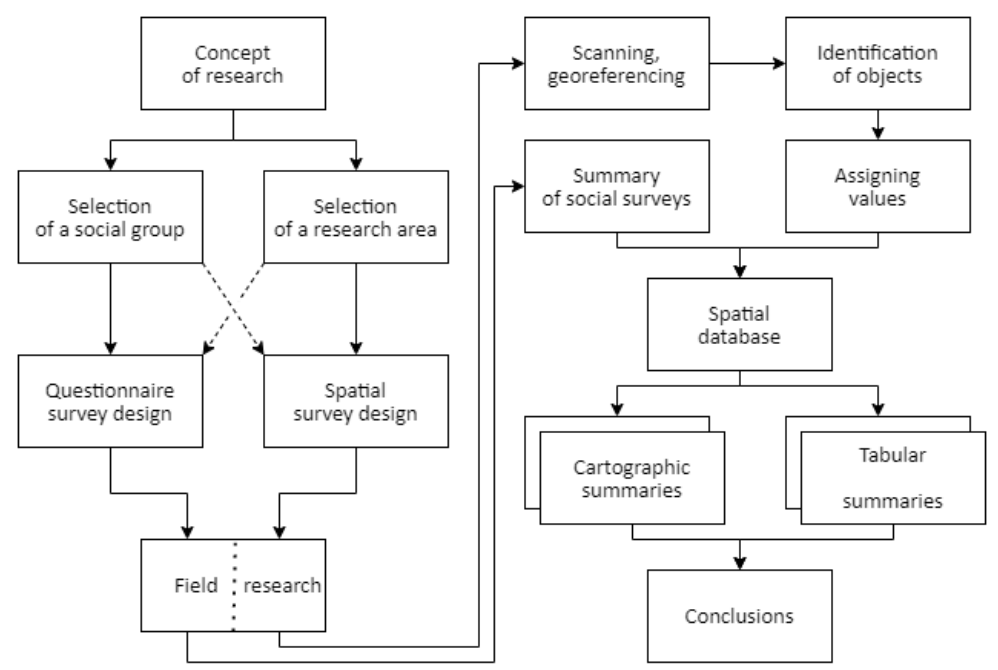

Fig. 4. Workflow of the analysis using mental maps and GIS software (source: own elaboration)

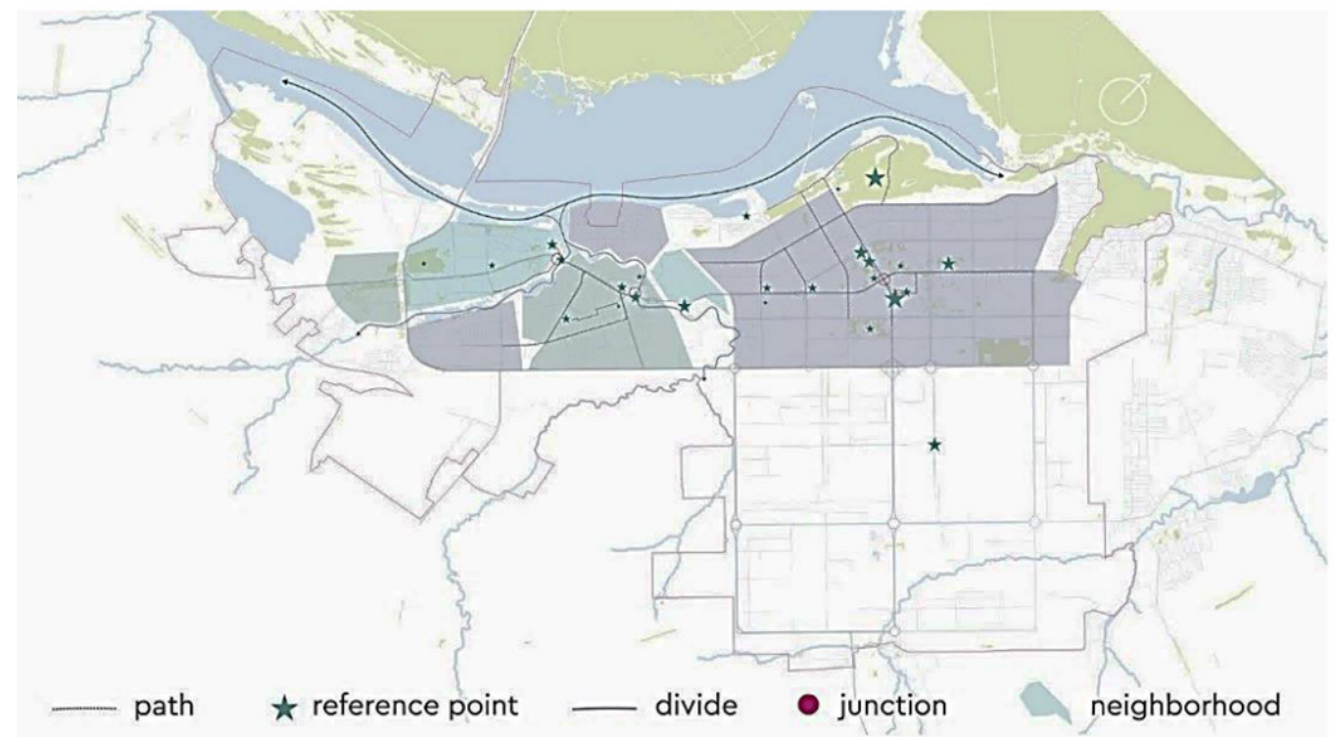

Fig. 5. Five categories of objects used in the analysis of mental maps of the city of Nabierieżnyje Czelny, Russia (Latypova et al., 2021)

results of mental maps analyses, is a method of signature symbols. Typical examples of maps created in such a way are collective maps with 5 object categories, as the Lynch's theory suggests. The categories are as follows: landmarks, nodes, edges, paths and districts. The map depicts only these elements whose frequency of indications was over average, or uses quantitative signature symbols differentiating the objects by the frequency of indications - below or over the average (fig. 5). In the presented research conducted in the city 


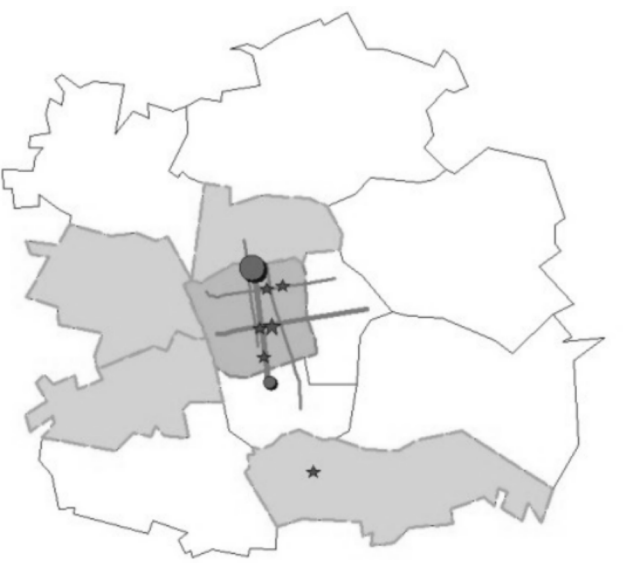

landmarks

다 25-37,5\%

$12,5-25 \%$

nodes

$37,5-50 \%$

$12,5-25 \%$

paths

50-62,5\%

$37,5-50 \%$

- 12,5-25\%

districts

[-] 25-37,5\% $12,5-25 \%$

Fig. 6. Four object categories extracted during the analysis of urban space perception of Łódź among male respondents (Tobiasz-Lis, 2008)

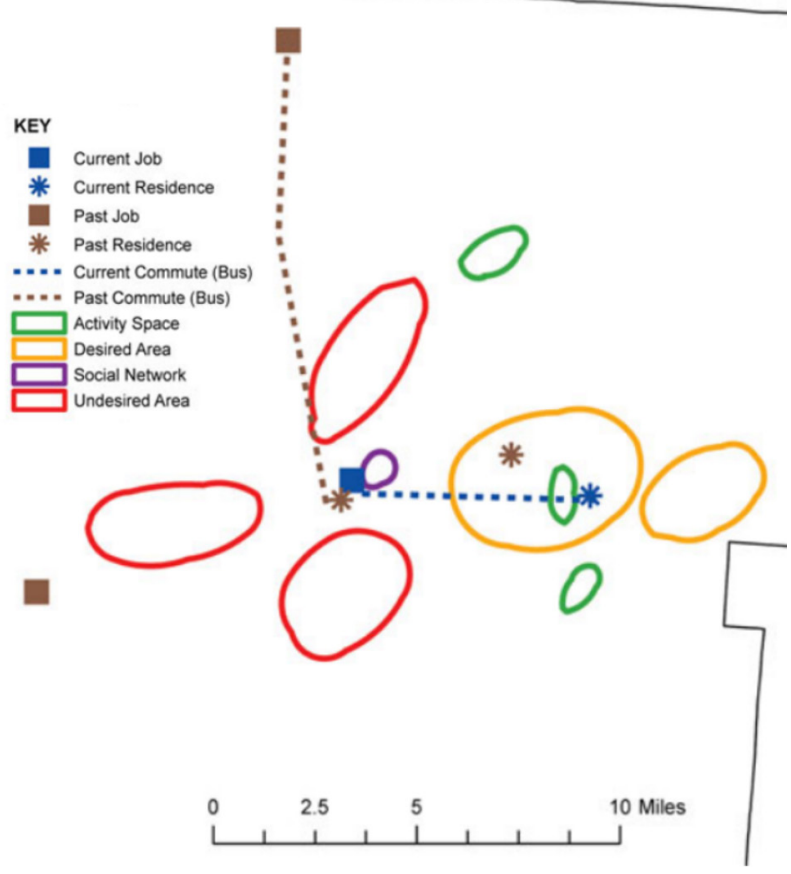

Fig. 7. Points, lines and polygons on a digitised sketch in Columbus, USA (Boschmann \& Cubbon, 2014)

of Nabierieżnyje Czełny, Russia, the authors used several classes reflecting the frequency of indications by the respondents. However, these classes are not included in the legend. It is also worth noting that the research area covered the whole city, which causes the landmarks to be close to each other and makes it difficult to edit the map. The authors aimed at covering the whole area in their research, which resulted in lower readability of the map.

Another example of implementing quantitative signature symbols is the presentation of urban space perception of the city of Łódź, Poland, by different groups of society (fig. 6). Numerous classes were used by the author for particular object categories. In this research, a large research area (whole city) affects the readability of a resulting map.

The authors also use the method of signature symbols showing individual categories of objects within the research area on digitized sketch map (fig. 7). In surveys where respondents are asked to describe (assess) the entire area, on maps presenting digitised individual sketches, colours are used to distinguish individual categories (for phenomena on a nominal or ordinal scale) (fig. 8). Respondents' answers do not always allow to cover the whole area with objects. When the phenomenon under study is on a nominal scale, such a map can be classified as an ordinal choropleth map.

In the analysis of mental maps, the researchers also use the range method (fig. 9). It is used to highlight the area of particular interest among respondents, or to emphasise the significance of a certain part of the city.

Methods illustrating the range of a given phenomenon can also be used in the presentation of distortions (error ellipses) attributed to indications of individual landmarks (fig. 10). 


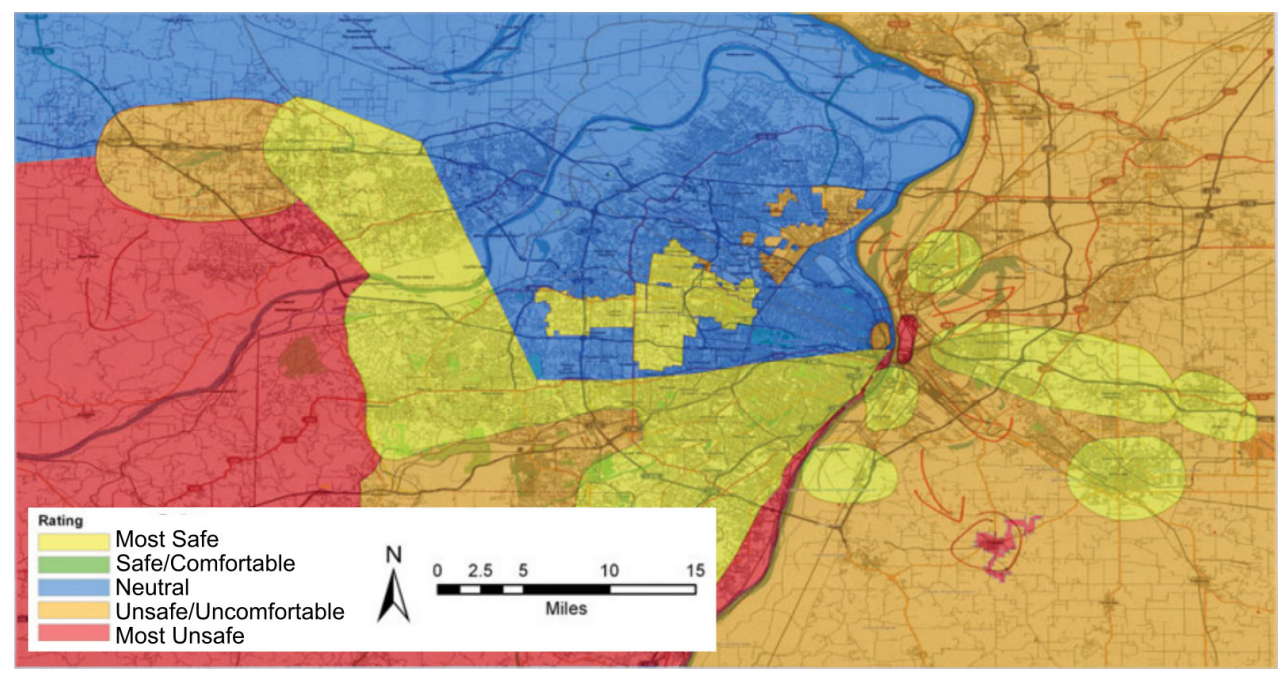

Fig. 8. Example of digitalisation of a sketch using colour differentiation of public space experience categories in St. Louis, USA (Boschmann \& Cubbon, 2014)

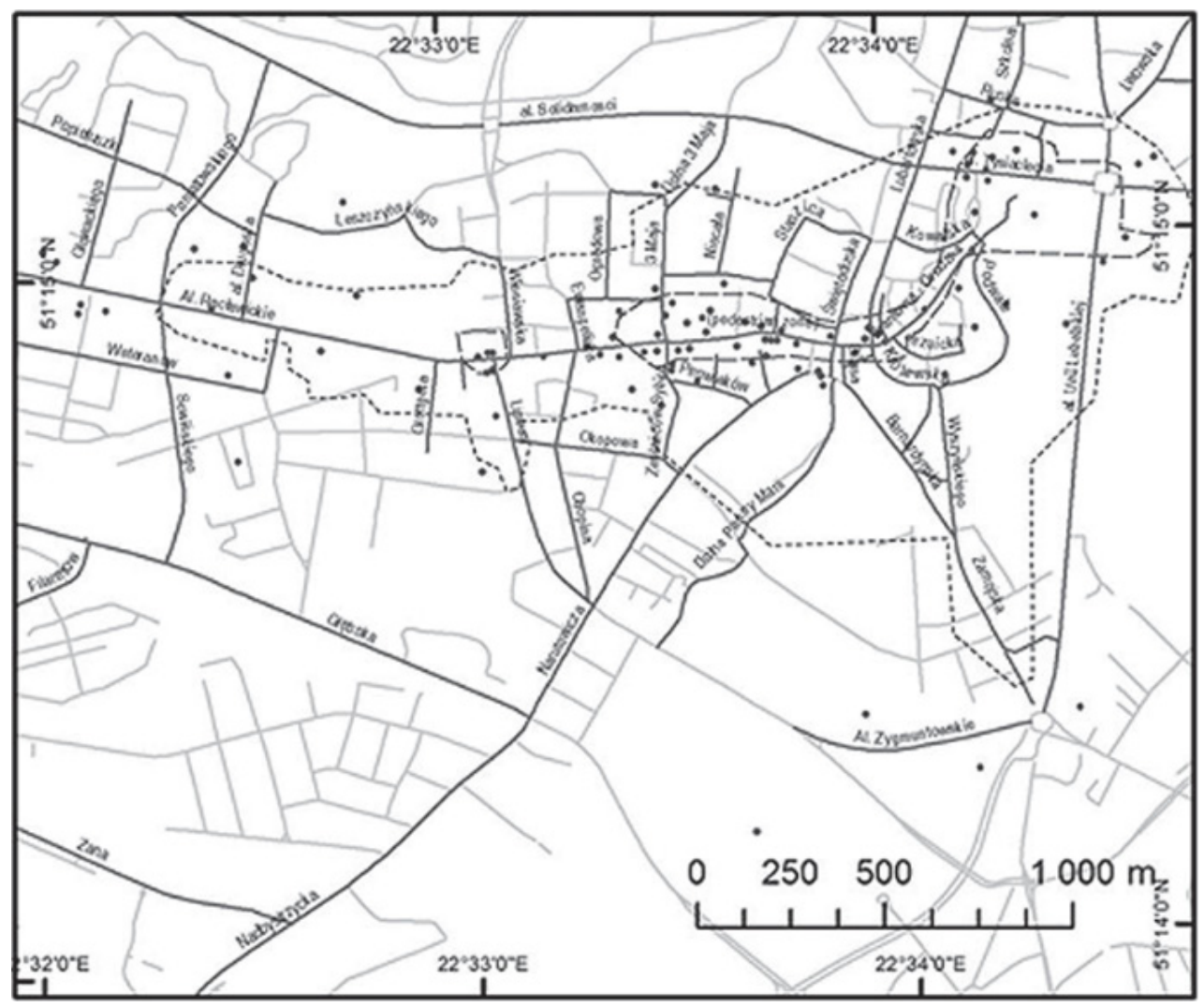

Fig. 9. Points of Interest marked by the respondents. Centre area identified according to over $10 \%$ of the respondents (dashed line) and $25 \%$ of the respondents (dotted line) - results of the research on urban space perception in Lublin (Nieścioruk, 2019b) 


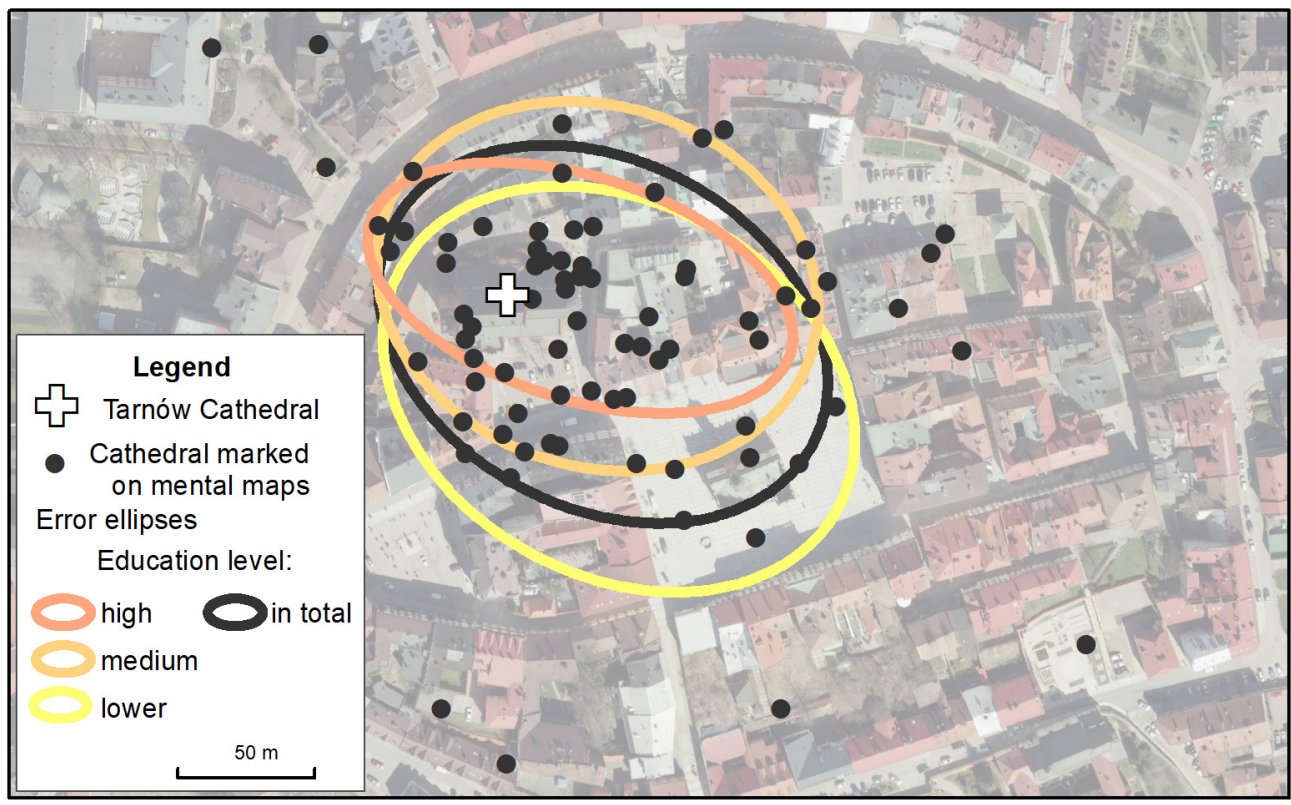

Fig. 10. Indications of the Tarnów Cathedral on mental maps picturing the city centre of Tarnów, along with their error ellipses, depending on the respondents' level of education (Kara-Ruta, 2019)

\subsection{Quantitative methods}

Quantitative methods in research on mental maps are not frequently used. It may result from several factors. Firstly, if the respondents are given full freedom while creating sketches, the summary of answers becomes a problematic issue. Secondly, using the method of quantitative signature symbols is frequently sufficient. Moreover, as it is shown in the literature, the differentiation between quantitative signature symbols and graduated symbol maps is often imperceptible (Korycka-Skorupa \& Pasławski, 2017). For example, the symbology of paths and nodes presented in figure 6 can be described as a graduated symbol map. It can certainly be done for quantitative presentation of the landmarks indicated in figure 2. In the same research, proportional line maps are also used to show the frequency of identification of given paths by the respondents (fig.11).

It needs to be noticed that the functionalities implemented in the most popular GIS programs (ArcGIS ArcMap, ArcGIS Pro, QGIS) do not provide tools for fully correct map redaction for the aforementioned mapping techniques. For example, in the case of proportional symbol maps in continuous scales, the automatically generated legends are unacceptable. It may encourage the use of graduated symbol maps with interval scale or replacing proportional symbol maps in continuous scales with quantitative signature symbol maps. The problems related to automatic redaction of cartographic materials in GIS programs were already noticed by Pasławski in his coursebook (Pasławski, 2010) and script (Pasławski, 2015).

Other quantitative mapping techniques which are used both in evaluative mapping and structural mapping are isopleth maps (fig. 1, fig. 12). Nieścioruk in his research on perception of the city centre implemented isopleths to show differences between analysed groups of society (Nieścioruk, 2019a). It needs to be stated that his research falls in between evaluative and structural mapping. ${ }^{4}$

\footnotetext{
${ }^{4}$ The present author suggests that the concept of city centres can be either a real spatial object whose perception of location can be analysed (structural mapping), or a strictly imaginary object (evaluative mapping).
} 


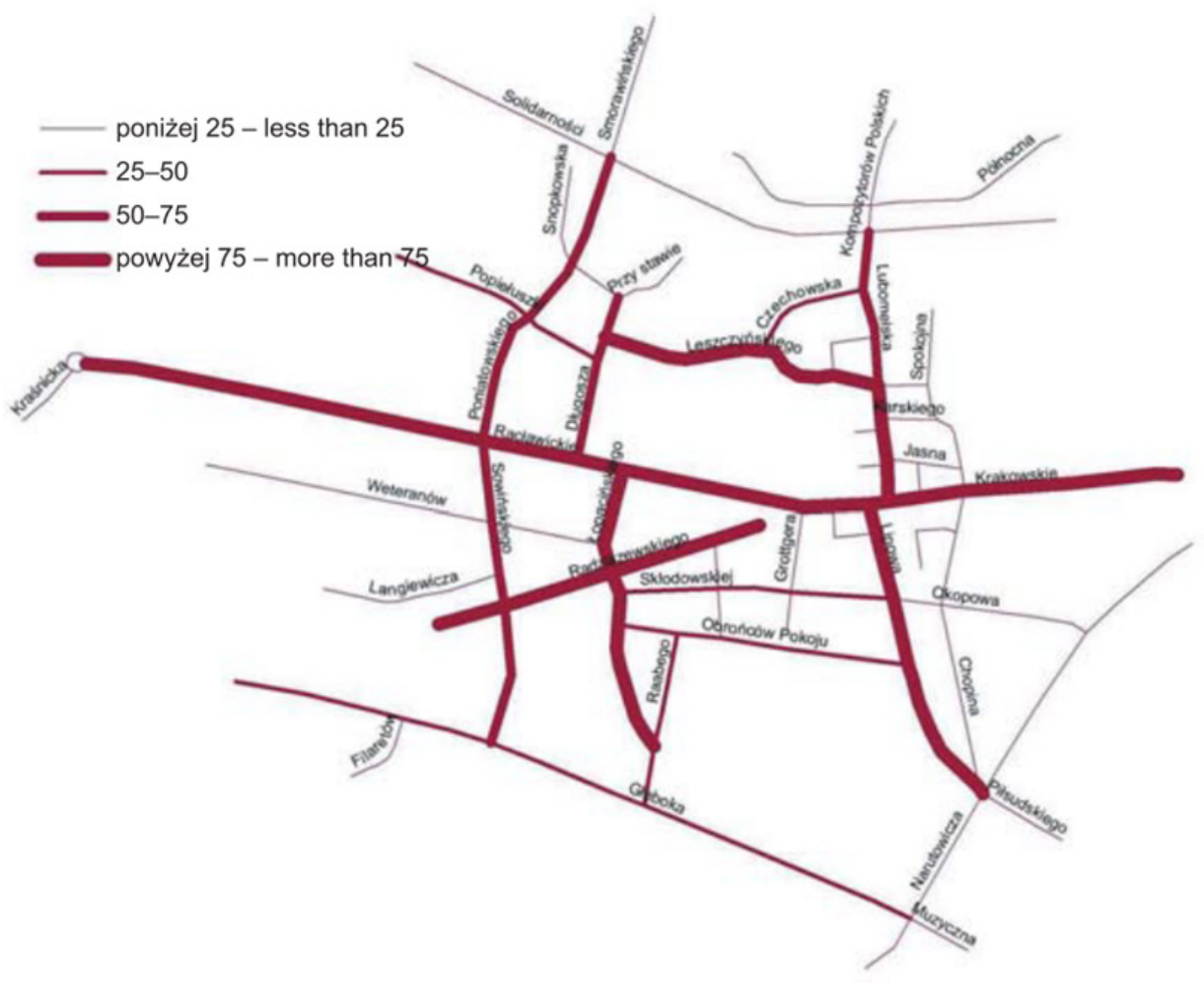

Fig. 11. Frequency of indications of particular paths on mental maps of Lublin (Nieścioruk, 2013)
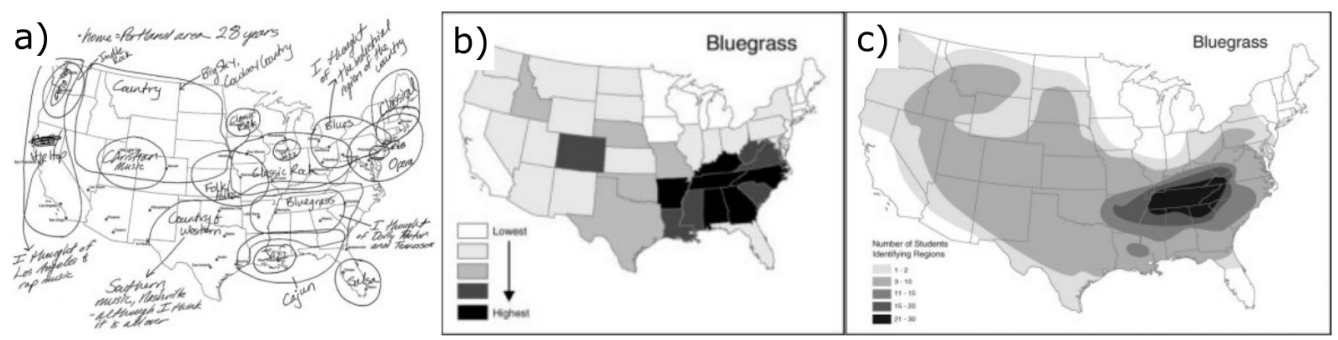

Fig. 12. Research on perception of domination of different music genres in the USA: a) sample mental map b) a choropleth map showing the frequency of indications of a particular music genre, c) an isopleth map based on the same source data as the choropleth map (Shobe \& Banis, 2010)

The least commonly used mapping technique for presenting the results of mental maps is a choropleth map (fig. 12). In its traditional form it is used only in evaluative mapping for small-scale maps. Shobe and Banis studied the perception of different music genres in geo- graphical context in the USA (Shobe \& Banis, 2010). They compiled the results into a choropleth map and an isopleth map.

The last method used for presenting the results of the analyses of mental maps is based on using different colour saturation in a relative 


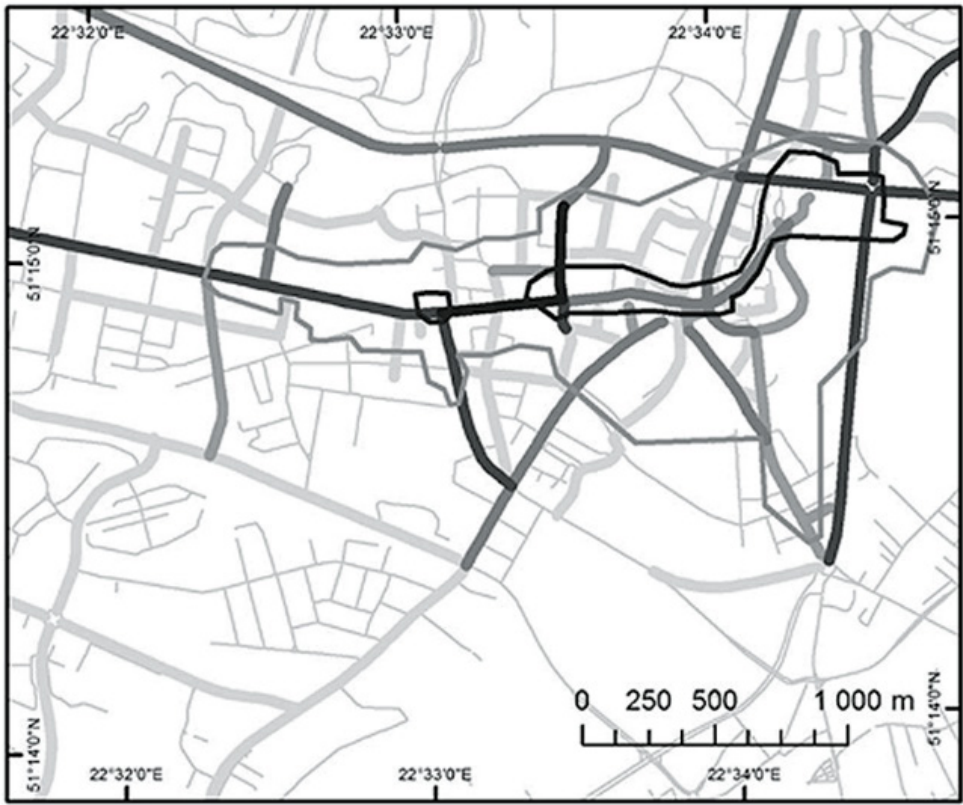

Number of participants including the street on their sketch maps

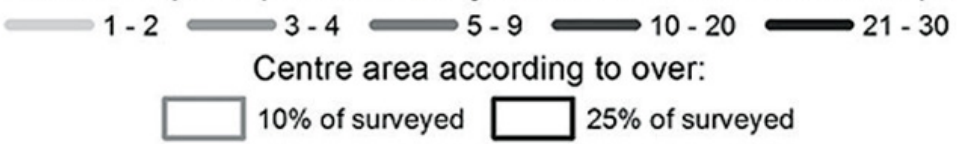

Fig. 13. Centre area on mental maps according to the number of respondents (Nieścioruk, 2019b)

way and bearing in mind the classification of a given phenomenon. Such a method of presentation could be named a method of quantitative signature symbols. Coloured signature symbols in the absolute manner are used by Nieścioruk (2019b) to present the number of indications for particular streets in the city centre (fig. 13). The same information could also be conveyed by compiling a proportional line symbol map. Then, however, due to a different width of road signatures, it would be difficult to present the number of indications on the same map.

The method of coloured signature symbols in its relative manner can also be used for showing the frequency of indications for buildings (Konieczkowska, 2018). In the research on perception of the whole AGH UST Campus (fig. 14), this approach was used to visualise how frequently the buildings administered by
AGH were identified by the respondents. ${ }^{5}$ It can be noticed that such a method is related to choropleth maps, particularly to dasymetric choropleth maps, as the visualisation of the phenomenon is limited only to areas (buildings) which are presented on the map. Mental maps created within the approach of structural mapping in large scales allow to analyse the data using various diagrams presenting the number of identifications within different groups of society (fig. 15). The same data could also be presented using a number of coloured signature symbol maps, but presenting all the result on one map is more readable.

\footnotetext{
${ }^{5}$ Research conducted as the part of the master thesis by Dominika Konieczkowska: "Using mental maps in the analysis of perception of AGH UST Campus with the use of ArcGIS software" 2018 (Department of Integrated Geodesy and Cartography, AGH UST, thesis supervisor - Stanisław Szombara, PhD).
} 


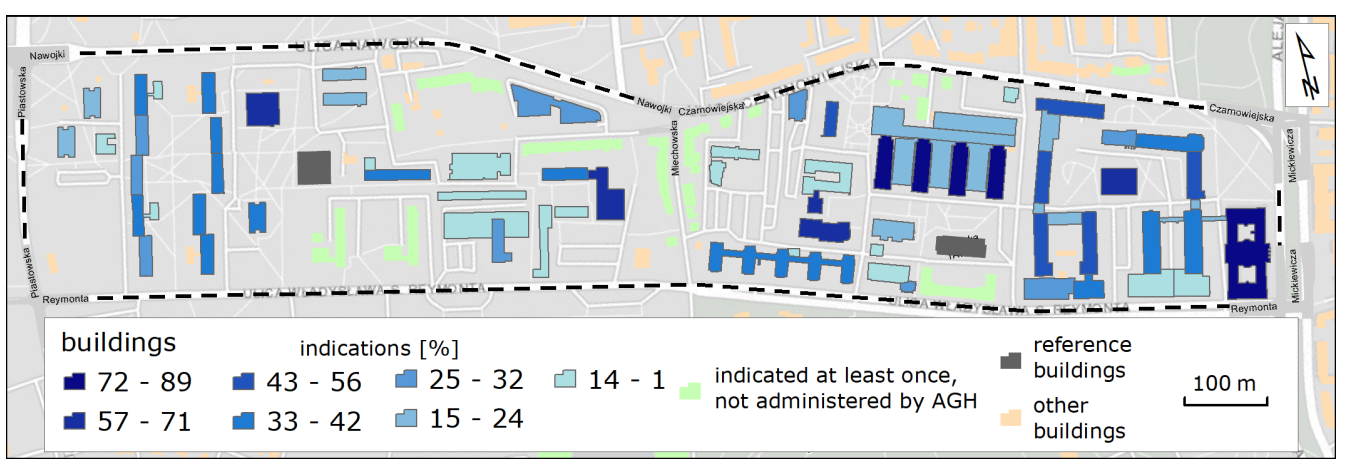

Fig. 14. Buildings administered by AGH marked by the respondents, according to the frequency of answers (source: own elaboration)

The software used in the research - ArcGIS ArcMap - allows to automatically create maps using the aforementioned methods (ordinal choropleth method, signature symbols, range method, choropleth method, proportional symbols, isopleths). The automatic creation of cartographically correct legends is achievable for qualitative methods. In the case of quantitative methods, it is possible to automatically generate a correct legend only for a small number of variants, e.g. for graduated circle maps in interval scale. For proportional circle maps in continuous scale, the legends are not correct.

\section{Conclusions}

The paper describes different mapping techniques applied in research using mental maps. Both qualitative and quantitative methods are used in evaluative and structural mapping. The method of signature symbols, range method and ordinal choropleth method are used in research conducted both in large and small scales. Quantitative methods, i.e. proportional symbol maps, quantitative signature symbols (relative and absolute) and isolines (isopleths, isochoropleths) are more frequently used in structural mapping which is conducted in large scales due to its nature. Due to the popularity of collective maps created in accordance with the Lynch's theory in structural mapping, a method of quantitative signature symbols is frequently used. They can be seen as the only maps presented in the summaries containing mostly tabular records. It is relatively rare to see in the literature complementary methods in one study. The comparison of choropleth maps and isopleth maps presented in figure 12 shows both advantages and disadvantages of these methods. On the one hand, using administrative divisions artificially increased the extent of the phenomenon presented on choropleth maps but, on the other hand, in the isopleth method there is a need for extensive data generalisation. This example presents well the complexity of the issue of cartographic presentation of summary mental maps analyses. It seems that implementing numerous complementary methods of cartographic presentation, i.e. proportional symbol maps (fig. 15), quantitative coloured signature symbol maps related to choropleth maps (fig. 14) and isopleth maps (fig. 1) could present a whole picture of the phenomenon of the perception of real world among people. Along with GIS software being more commonly used, it is possible to use a wide range of mapping techniques.

GIS tools not only make it possible to process and visualise cartographic data but also can be used for data acquisition. Such an approach is particularly possible in evaluative mapping (Walenciak et al., 2017a, 2017b). The respondents answer the questions in a so-called geo-survey. They indicate analysed objects directly on the screen of a computer or mobile device. Such an approach gives quite a big advantage over traditional questionnaires used in evaluative mapping because it is no longer necessary to digitize collected data. However, using topographic background maps or orthophotomaps imposes the picture of the world to the 


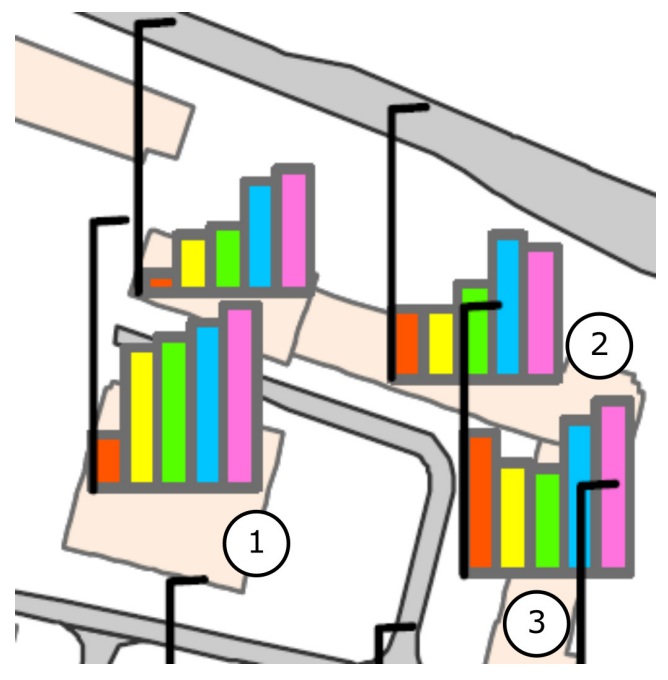

Fig. 15. A part of the map with proportional line symbols showing the number of indications for particular buildings by the first-, second-, third-, fourth- and fifth-year students. A vertical line marks $100 \%$ of indications. 1 - library, 2 - faculty building with the Division for Student Affairs, 3 - administration building where student ID cards are prolonged (source: Konieczkowska, 2018)

respondents, which in structural mapping would inevitably lead to distortion of a cognitive map

\section{References}

Bazan-Krzywoszańska, A., Mrówczyńska, M., \& Skiba, M. (2015). Badania Percepcji Mieszkańców Zielonej Góry - Mapy Mentalne. Czasopismo Inżynierii Lądowej, Środowiska i Architektury, XXXII(62,4), 19-32. https://doi.org/10.7862/rb.2015.175

Birnbaum, M.H., Anderson, C.J., \& Hynan, L.G. (1989). Two Operations for "Ratios" and "Differences" of Distances on the Mental Map. Journal of Experimental Psychology: Human Perception and Performance, 15(4), 785-796. https://doi. org/10.1037/0096-1523.15.4.785

Bláha, J.D., \& Nováček, A. (2016). How Central Europe is Perceived and Delimited. Mitteilungen Der Österreichischen Geographischen Gesellschaft, 158, 193-214. https://doi.org/10.1553/moegg158s193

Błahut, G. (2013). Mapy mentalne jako wyobrażenia miejskich obszarów kulturowych. Studia Etnologiczne i Antropologiczne, 13, 47-56.

Boschmann, E.E., \& Cubbon, E. (2014). Sketch Maps and Qualitative GIS: Using Cartographies of in the respondents' minds. It needs to be noticed that a continuous growth of popularity of mobile devices and navigation applications among the society imposes using novel ways of collecting data during conducting surveys (Dane et al., 2020). Applying such technologies in the field of mental maps requires further research.

GIS programs are becoming better and more advanced in terms of correct cartographic presentation. However, they are designed for dealing with multiple spatial issues, not only data visualisation. That is why some functionalities for generating map elements might not operate optimally from the cartographic point of view. These issues are not given a high priority by software developers. GIS programs are frequently compared against one another but rarely are the aforementioned functionalities taken into account (Österman, 2014; Stuckey, 2016). Although constant changes of software versions are desirable bearing in mind the software's development, these changes make it difficult to compare implemented cartographic functionalities. Nonetheless, such research certainly needs to be conducted.

\section{Acknowledgements}

This research was funded by the AGH University of Science and Technology research subsidy no. 16.16.150.545 in 2021.

Individual Spatial Narratives in Geographic Research. Professional Geographer, 66(2), 236-248. https://doi.org/10.1080/00330124.2013.781490

Brennan-Horley, C., \& Gibson, C. (2009). Where is creativity in the city? Integrating qualitative and GIS methods. Environment and Planning A, 41(11), 2595-2614. https://doi.org/10.1068/a41406

Castellar, S.M.V., \& Juliasz, P.C.S. (2018). Mental map and spatial thinking. In C.A. Brewer (Ed.), Proceedings of the ICA, 1 (18). https://doi.org/ 10.5194/ica-proc-1-18-2018

Comenetz, J. (2005). Mental Mapping: A Lesson That Creates Itself. Journal of Geography, 104(3), 113-118. https://doi.org/10.1080/00221340508978624

Dane, G.Z., Derakhshan, S., Ettefagh, T., Massari, M., Gianfrate, V., \& Bigi, M. (2020). Participatory mapping of citizens experiences at public open spaces: a case study at Bologna living lab. In Proceedings of 25th International Conference on Urban Planning and Regional Development in the Information 
Society GeoMultimedia 2020, (pp. 645-654). https://archive.corp.at/cdrom2020/papers2020/ CORP2020_91.pdf

Gendźwiłł, A. (2009). O prezentacji kartograficznej wyników badań map poznawczych. Polski Przegląd Kartograficzny, 41(2), 115-127.

Gould, P. (1966). On mental maps. University of Michigan.

Jarecka-Bidzińska, E. (2021). Hybrid methodology of multi-sensory research of public space in urban planning. Budownictwo i Architektura, 20(2), 95-116. https://doi.org/10.35784/bud-arch.2198

Jász, B. (2018). Mental map of the city: Elements of visual argumentation and creativity in modern city planning. Creativity Studies, 11(2), 284-293. https:// doi.org/10.3846/cs.2018.6901

Kara-Ruta, K. (2019). Wykorzystanie map mentalnych do analizy percepcji okolic rynku miasta Tarnowa $\mathrm{z}$ zastosowaniem oprogramowania ArcGIS [Master thesis]. AGH University of Science and Technology.

Kitchin, R.M. (1994). Cognitive maps: What are they and why study them? Journal of Environmental Psychology, 14(1), 1-19. https://doi.org/10.1016/ S0272-4944(05)80194-X

Konieczkowska, D. (2018). Wykorzystanie map mentalnych do analizy percepcji przestrzeni kampusu AGH z zastosowaniem oprogramowania ArcGIS [Master thesis]. AGH University of Science and Technology.

Korycka-Skorupa, J., \& Pasławski, J. (2017). O sygnaturach ilościowych. Miejsce sygnatur ilościowych w klasyfikacji kartograficznych metod prezentacji. Polish Cartographical Review. Suplement w języku polskim, 2(2), 191-199.

Kum, T.L., \& Ujang, N. (2012). The application of mental mapping technique in identifying the legible elements within historical district of Kuala Lumpur city centre. Alam Cipta, 5(1), 55-62.

Latypova, M., Mingalimova, E., Rubtsova, A., \& Tazov, A. (2021). Empirical study of the mental representation of the image of the city (on the example of Kazan and Naberezhnye Chelny). In E. Vdovin (Ed.), 2nd International Scientific Conference on Socio-Technical Construction and Civil Engineering (STCCE - 2021), E3S Web of Conferences, 274, 01034.https://doi.org/10.1051/e3sconf/202127401034

Lee, M.Y., Hitchcock, M., \& Lei, J.W. (2018). Mental mapping and heritage visitors' spatial perceptions. Journal of Heritage Tourism, 13(4), 305-319. https://doi.org/10.1080/1743873X.2017.1350187

Lynch, K. (1960). The Image of the City. M.I.T. Press. Nieścioruk, K. (2013). Kartograficzny obraz map mentalnych przestrzeni miejskiej i jego prezentacja oraz analiza z zastosowaniem narzędzi systemów informacji geograficznej. Acta Scientiarum Polonorum. Geodesia et Descriptio Terrarum, 12(4), 27-40.
Nieścioruk, K. (2016). The Use of Mental and Sketch Maps as a Tool to Evaluate Cartography Teaching Effectiveness. Cartographic Journal, 53(2), 186-196. https://doi.org/10.1080/00087041.2015.1108064

Nieścioruk, K. (2019a). Cartographic Delimitation of the City Centre Using Mental Sketches. Cartographic Journal, 56(4), 355-367. https://doi.org/10.10 80/00087041.2018.1547472

Nieścioruk, K. (2019b). Learning the space. The change of spatial cognition of a city centre by high-school students in the light of mental maps and sketches. In Mental Mapping. The Science of Orientation. New Approaches to Location - Spatial Patterns of the Global Economy Conference (pp. 187-199). Schenk Verlag. https://doi.org/ 10.14267/978-3-944850-78-8_11

Österman, A. (2014). Map visualization in ArcGIS, QGIS and MapInfo [Degree Project]. KTH Royal Institute Of Technology. http://kth.diva-portal.org/ smash/get/diva2:729183/FULLTEXT01.pdf

Pasławski, J. (Ed.). (2010). Wprowadzenie do kartografii i topografii. Nowa Era.

Pasławski, J. (2015). Jak opracować mapę kropkową. Wydział Geografii i Studiów Regionalnych UW.

Rédei, M., Kincses, Á., \& Jakobi, Á. (2011). The world seen by Hungarian students: A mental map analysis. Hungarian Geographical Bulletin, 60(2), 135-159.

Shobe, H., \& Banis, D. (2010). Music regions and mental maps: Teaching cultural geography. Journal of Geography, 109(2), 87-96. https://doi.org/10.10 $80 / 00221341.2010 .482160$

Sobala-Gwosdz, A. (2018). Osobiste doświadczenie przestrzeni miasta jako czynnik zmian wyobrażeń i stereotypów przestrzennych. In S. Sitek (Ed.), "Stare i nowe" problemy badawcze w geografii społeczno-ekonomicznej (pp. 71-84). Polskie Towarzystwo Geograficzne Oddział Katowicki, Uniwersytet Śląski Wydział Nauk o Ziemi.

Stuckey, O. (2016). A comparison of ArcGIS and QGIS for animation. Cartographic Perspectives, 2016(85), 23-32. https://doi.org/10.14714/CP85.1405

Sulsters, W.A. (2005). Mental mapping, viewing the urban landscapes of the mind. In International Conference "Doing, Thinking, Feeling Home: The Mental Geography of Residential Environments" (pp. 1-5). Delft University of Technology.

Tobiasz-Lis, P. (2008). Wyobrażenia kobiet i mężczyzn o przestrzeni Łodzi. Acta Universitatis Lodziensis. Folia Geographica Socio-Oeconomica, 9, 147-162.

Ujma, P. (2017). Wykorzystanie map mentalnych do analizy percepcji przestrzeni kampusu AGH z zastosowaniem oprogramowania ArcGIS [Master thesis]. AGH University of Science and Technology.

Walenciak, K., Kozieł, Z., \& Antolak, M. (2017a). Methodical and technological assumptions for using of the participatory GIS method in planning and 
revitalization of urban green space (part 1). Geoinformatica Polonica, 16, 19-33. https://doi.org/10 $.4467 / 21995923 g p .17 .002 .7189$

Walenciak, K., Kozieł, Z., \& Antolak, M. (2017b). Some issues in planning and revitalization of urban green space in the light of use of the participatory GIS method based on Olsztyn geosurvey - study results (part 2). Geoinformatica Polonica, 16, 35-51. https://doi.org/10.4467/21995923gp.17.003.7190

Żyszkowska, W. (1996). Mapy mentalne Polski uczniów klas licealnych. Polski Przegląd Kartograficzny, 28(1), 9-29. 